\title{
Greek Migrant Literature in the Early Roman Empire
}

\author{
Casper C. de Jonge \\ Leiden University, Centre for the Arts in Society/Classics \\ c.c.de.jonge@hum.leidenuniv.nl
}

Received February 2021 | Accepted July 2021

\begin{abstract}
This article argues that the concept of migrant literature, developed in postcolonial studies, is a useful tool for analysing Greek literature of the Early Roman Empire (27 BC-AD 68). The city of Rome attracted huge numbers of migrants from across the Mediterranean. Among them were many writers from Hellenized provinces like Egypt, Syria and Asia, who wrote in Greek. Leaving their native regions and travelling to Rome, they moved between cultures, responding in Greek to the new world order. Early imperial Greek writers include Strabo of Amasia, Dionysius of Halicarnassus, Nicolaus of Damascus, Timagenes of Alexandria, Crinagoras of Mytilene, Philo of Alexandria and Paul of Tarsus. What connects these authors of very different origins, styles, beliefs, and literary genres is migrancy. They are migrant writers whose works are characterized by in-betweenness, ambivalence and polyphony.
\end{abstract}

\section{Keywords}

migration - migrant literature - in-betweenness - identities - cultural mobility Greek literature in the Roman world

\section{Introduction}

The Early Roman Empire (27 BC-AD 68) was an age of migration. The city of Rome attracted huge numbers of migrants from across the Mediterranean. While cultural mobility was not new in this period, the foundation of a 
globalized empire gave a new impulse to migration, with an unprecedented impact on literature. Among the migrants were many writers from Hellenized provinces like Egypt, Syria and Asia, who wrote in Greek. They include Strabo of Amasia and Dionysius of Halicarnassus, Nicolaus of Damascus, Crinagoras of Mytilene, Philo of Alexandria and Paul of Tarsus: a geographer, a rhetorician, a historian, a poet, a Jewish philosopher and an early Christian apostle. Leaving their native regions and travelling to Rome, they moved between cultures, responding in Greek to the new world order.

We know that foreign cultures had a tremendous impact on Rome. Yet remarkably little is known about how migrants perceived their own role in the Roman world. Cultural identity must be distinguished from ethnic identity: migrant writers consciously adopted a Greek style, associating themselves

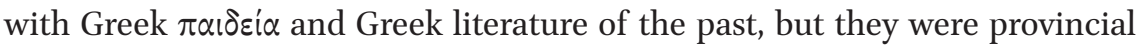
natives, while fully participating in the social and political systems of the Roman Empire. How does Greek literature of the Early Roman Empire present, reflect and construct the complex interaction between Greek, Roman and local identities? In this article I will argue that the literature written in Greek between 27 BC and AD 68 is neither Greek literature (as it is traditionally classified) nor Roman literature, but 'migrant literature'. Migration seems to have been almost a prerequisite for writing literature in this period: no literature in Greek seems to have survived from this age that was not directly or indirectly the result of cultural mobility.

The concept of migrant literature has been developed in the context of postcolonial studies. It has been shown that the literature produced by migrants is characterized by in-betweenness, ambivalence, and polyphony. Without claiming that ancient migration and modern migration are identical, I will argue that these three categories are essential to our understanding of the works written in Greek in the Julio-Claudian age. ${ }^{1}$ Greek literature of the Early Roman Empire can be considered migrant literature that moves between Greek, Roman and local identities, giving voice to ambivalent and polyphonic responses to Rome.

1 While this article concentrates on the literature written between $27 \mathrm{BC}$ and AD 68, it is obvious that migration and migrant literature are also highly relevant notions for understanding Greek literature of the later Hellenistic period (e.g. Diodorus Siculus, Philodemus of Gadara) and the Second Sophistic (e.g. Dio of Prusa, Aelius Aristides). 
The last decades of the twentieth and the first decades of the twenty-first centuries have seen a dramatic upsurge of interest in the Greek literature in the Roman world. Three stages can be discerned in this debate.

(1) In 1996 Simon Swain published Hellenism and Empire. Language, Classicism, and Power in the Greek World AD 50-250. This book examines "how the leading Greek intellectuals viewed Rome and Roman power in Greece and the Greek world". ${ }^{2}$ Notwithstanding its great merits, the book has two serious limitations. First, when examining Greek texts, Swain looks for explicit pro- or antiRoman statements ("acceptance" or "resistance"), thus ignoring more implicit, nuanced and ambiguous utterances. Second, Swain rather easily assumes that authors of Greek literature are 'Greeks', without considering the enormous diversity of the local regions from which these authors were writing. ${ }^{3}$

(2) In 2001 these problems were addressed in two publications: Tim Whitmarsh's ground-breaking monograph on constructions of Greek identity in the Roman Empire and Simon Goldhill's important volume Being Greek under Rome. Cultural Identity, the Second Sophistic and the Development of Empire. ${ }^{4}$ These studies are not just interested in Greek texts that engage in explicit praise or criticism of Rome, but draw attention to more subtle discursive strategies. Furthermore, they rightly argue that the Greek identity of the authors of Greek imperial literature is a cultural identity, which is not to be confused with ethnic identity. ${ }^{5}$ Imperial authors deliberately adopted Greek styles, associating themselves with classical Greek language, literature and ideas. ${ }^{6}$ Despite this important insight, most of the essays in Being Greek under Rome do not sufficiently address the local identities of the Greek authors of the Roman world. ${ }^{7}$ The title of the volume itself still suggests a binary opposition between Rome and Greece, ignoring the crucial differences between places like Chaeronea, Prusa, or Samosata. ${ }^{8}$

2 Swain 1996, 1.

3 For criticism of Swain 1996, see the essays in Goldhill 2001.

4 Whitmarsh 2001a; Goldhill 2001.

5 Goldhill 2001, 15-20; Whitmarsh 2001b, 305.

6 See also Dupont and Valette-Cagnac 2005.

7 Whitmarsh $2001 \mathrm{~b}$ is one of the important exceptions.

8 Cf. Woolf 1994: "Becoming Roman, Staying Greek"; Connolly 2007: "Being Greek/Being Roman". 
(3) The importance of local perspectives has been powerfully put forward in the volume Local Knowledge and Microidentities in the Imperial Greek World. ${ }^{9}$ The essays in this book rightly draw attention to the fact that the globalization of the Roman Empire went hand in hand with a new focus on local identities. ${ }^{10}$ It includes essays on microidentities in Crete, Termessus (in Anatolia), and Paphlagonia (near the Black Sea). The volume does however not address the fact that many authors of Greek imperial literature were migrant writers.

\section{A New Approach: Migrant Literature in the Early Roman Empire}

This article proposes a research agenda that aims to change the debate on Greek Literature in the Roman World in two ways: (a) it reads Greek literature of the Early Roman Empire no longer as 'Greek literature', but as 'migrant literature'; and (b) it shifts the attention from the so-called Second Sophistic (AD 50-25O) to the earliest period of the Roman Empire (27 BC-AD 68). Let me explain these two moves.

\section{(a) Globalization, Migration and Migrant Literature}

Greek literature of the Roman world is not literature produced by writers from Greece; it is literature written in the Greek language, by authors who came from many different places around the Mediterranean. Many of them had Roman citizenship. ${ }^{11}$ These writers were as diverse as their audiences and the literary genres in which they wrote.

From the end of the fourth century BC, after the conquests of Alexander the Great, the Greek language and Greek education ( $\pi \alpha \iota \delta \varepsilon i \alpha)$ had been adopted in cities all over the (Eastern) Mediterranean world. Hellenism played an important role in multicultural places like Alexandria, Damascus, and Halicarnassus, where Greek elite communities and local communities coexisted. ${ }^{12}$ Under the Roman Empire, Alexandria, Damascus and Halicarnassus had become part of Roman provinces like Egypt, Syria and Asia. All these different communities were now interconnected, interdependent and united into one Empire: this process of globalization went hand in hand with a substantial increase of

9 Whitmarsh 2010.

10 See esp. Whitmarsh 2010, 4-8; Woolf 2010.

11 It is often assumed that Strabo of Amasia had Roman citizenship because the name Strabo was also a Roman cognomen: see Dueck 2000, 5-8. The father or grandfather of Philo of Alexandria received Roman citizenship from Julius Caesar. According to Acts 22:25-29, Paul of Tarsus was a Roman citizen.

12 See e.g. Kuhrt and Sherwin-White 1987; Millar 1987; Millar 1993. 
migration, which was facilitated through the well-organized network of roads and waterways in the Roman Empire. ${ }^{13}$

Migration was certainly not a new phenomenon in the Roman Empire. ${ }^{14}$ But the foundation of the Empire gave an unprecedented impulse to migration, in particular migration to Rome..$^{15}$ Intellectuals from all parts of the Roman Empire came to Rome, simply because it was the place to be: there they would not only find work, but also students, colleagues writing in Greek or Latin, and, most importantly, Roman patrons who were willing to support their writing activities. While historians have paid due attention to processes of ancient migration, the ancient literary perspectives on migrancy are understudied, despite the 'spatial turn' that has resulted in studies of motion and space in ancient literature. ${ }^{16}$

The authors of Greek texts from the Early Roman Empire whose lives we can reconstruct have three things in common: they wrote in Greek, they travelled extensively, and they all went to Rome. Some of them returned home after spending some time in the Roman capital (like Philo of Alexandria), others decided to stay there for many years (like Strabo of Amasia) or for the rest of their lives (Dionysius of Halicarnassus, Timagenes of Alexandria, Antipater of Thessalonica and presumably Nicolaus of Damascus); some went there to die (Paul of Tarsus). In all cases we can tell that the experience of migration to Rome had a fundamental impact on their literary writing: it transformed their intellectual outlook. This was reflected in their literary writing, which voices fascinating responses to Rome and sophisticated reflections on the interaction between Greek, Roman and local cultures.

Although migration is in fact a defining aspect of early Greek imperial literature, migrant literature is not a prominent category in studies on Greek literature of the Roman world. Two important studies however must be mentioned as pointing in this direction. Tim Whitmarsh has drawn attention to the genre of "exile literature" in the Second Sophistic, showing that authors like Dio of Prusa, Musonius and Favorinus (end of the first/second century AD) employ the language of exile in order to construct their cultural identity. ${ }^{17}$ Exile might be considered one type of migration, which has its own connotations. ${ }^{18}$ While

\footnotetext{
13 On globalization and the Roman Empire, see Pitts and Versluys 2015; Versluys 2016.

14 See Hezser 2011 on Jewish mobility; Garland 2014 on migration in the archaic and classical Greek world; Isayev 2017 and Garland 2018 on migration in ancient Italy.

15 De Ligt and Tacoma 2016; Tacoma 2016; Woolf 2016.

16 On space and motion in ancient literature, see de Jong 2012; Hutchinson 2020.

17 Whitmarsh 2oorb.

18 Mardorossian 2002 discusses the different connotations of literature of exile and migrant literature from a modern theoretical perspective; see also Savin 2013.
} 
the body of ancient exile literature is relatively limited, migrant literature covers roughly all extant Greek texts of the Early Roman Empire. More recently, Joy Connolly has proposed to understand the rhetorician and historian Dionysius of Halicarnassus as a "migrant thinker", who was moving between cultures and genres. ${ }^{19}$

(b) Greek Literature in the Early Roman Empire (27 BC-AD 68)

Since the publication of Ewen Bowie's now classic essay on 'Greeks and their Past in the Second Sophistic', scholarship on Greek literature in the Roman world has largely concentrated on the period from ca. AD 50 to $25^{\circ} .{ }^{20}$ Our understanding of the Greek literature of the Julio-Claudian age (27 BC-AD 68) however is rather limited: this is simply a neglected period in the study of Greek literature. One reason may be that the writings of this age are so diverse (epigram, geography, rhetoric, historiography, letters etc.) that a coherent interpretation of this corpus is a real challenge.

This neglect is problematic, because the Early Roman Empire was precisely the age in which a 'cultural revolution' transformed society, culture and identities. ${ }^{21}$ The rule of the Julio-Claudian emperors had an enormous impact on migration, but also on literature and the formation of cultural identities. The foundation of an Empire that stretched from Spain to Syria, ruled by one single man, forced intellectuals from all parts of the Mediterranean to rethink the world and their own role in it: how to respond to Rome? On an unprecedented scale Greek literature of the Early Roman Empire engages in questions concerning identities and the cultural interaction between Greece, Rome and local regions. Thus we see that, within a few years after becoming the first princeps, Augustus himself makes his appearance in Greek epigram, historiography and biography. ${ }^{22}$ While there are obvious continuities between Hellenistic literature and imperial Greek literature, the direct engagement of Greek writing with Rome and Roman power was new. It is also in this age that we can discover the beginnings of the formation of a Greek cultural identity, the deliberate adoption of language, styles and notions that were associated with (classical) Greekness: this has been a hot topic in studies on the Second Sophistic, but we need to shift our attention to the earlier period in order to understand how it was triggered by the cultural revolution of the Roman

\footnotetext{
19 Connolly 2019.

20 Bowie 1970.

21 Wallace-Hadrill 2008.

22 See Hose 2018.
} 
Empire. While an overall interpretation of Greek literature in the Early Roman Empire is a desideratum, significant work has recently been done on individual authors, like Strabo, Dionysius, Crinagoras; and thanks to recent publications we know more than ever about Greek literature before the Second Sophistic. ${ }^{23}$

The concept of migrant literature has been developed in postcolonial literary studies. ${ }^{24}$ It has proven its value in studies on contemporary literature, but in scholarship on ancient literature it is rather new. ${ }^{25}$ The model is particularly useful for interpreting the polymorphic corpus of Greek literature of the Early Roman Empire, as cultural mobility was one of its defining dimensions. Migrant literature is here understood as literature produced by writers who temporarily or permanently moved away from their native region, narrating experiences of migration, and more generally reflecting a cosmopolitan society deeply characterized by cultural mobility.

Starting from the later 1980 os the category of migrant literature has been used to analyse the literary output of a group of writers whose geographic and cultural affiliations are unstable, dynamic and displaced. ${ }^{26}$ They include authors like Salman Rushdie, Ben Okri, Vikram Seth, and many others. Migration plays an important role both in the lives of these authors and in their work. Cultural interaction is a dominant theme of their novels, which typically move across geographical, cultural and historical spaces.

Before we apply the modern concept of migrant literature to ancient texts, we must ask whether ancient and modern migration are the same thing. There are two important differences between ancient and modern migration. First, modern models of migration are closely associated with the crossing

23 Dueck 2017 on Strabo; Hunter and de Jonge 2019 on Dionysius; Ypsilanti 2018 on Crinagoras. Schmitz and Wiater 2011 have produced an important volume on Greek cultural identity in the first century BC. Whitmarsh 2013a problematizes the scholarly obsession with the Second Sophistic and draws attention to other texts and periods. König and Wiater forthcoming examine cross-generic dialogues in "Late-Hellenistic Literature" from Polybius to Strabo.

24 Bhabha 1994; White 1995; Smith 2004; Boehmer 2005, 225-236: "The writing of 'not quite' and 'in-between'".

25 See e.g. Savin 2013; Vlasta 2016; Nyman 2017. Connolly 2019 portrays Dionysius as a "migrant thinker".

26 Boehmer 2005, 225. 
of borders between nation states: these did not exist in the ancient world. ${ }^{27}$ Second, the colonial relationship between the modern western world and formerly colonized countries differs from that between Rome and its (Hellenized) provinces. Most importantly, the status of Greek culture in Rome was unlike that of any modern colonized region. The deliberate adoption of a Greek style (Hellenism) could be practiced by Romans, Greeks and locals alike, forming a kind of common ground (and language) between different cultures. ${ }^{28}$ The position of French, Spanish or English in the twentieth and twenty-first centuries is quite different, as (unlike ancient Greek) these languages are primarily associated with the colonizing power.

That being said, there are many parallels between twenty-first century migration and mobility in the Early Roman Empire. ${ }^{29}$ First, as much as the twenty-first century world, the Roman Empire was a globalized world, in which cultural interaction played a dominant role. ${ }^{30}$ Second, much like the twenty-first century, the Early Roman Empire was an age of massive mobility, with an enormous impact on literature, so much that 'migrancy' (referring to migration as a condition of human life) is indeed a defining factor of Greek literature of this period. ${ }^{31}$ These writers might refer to themselves as 'traveller

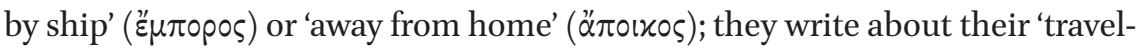
ing' ( $\pi \circ p \varepsilon i \alpha)$ and 'being away from home' ( $\dot{\alpha} \pi \circ \delta \eta \mu \varepsilon i v)$. But they could also refer to their 'displacement' ( $\mu \varepsilon \tau \alpha \nu \alpha \dot{\sigma} \sigma \alpha \sigma \varsigma)$ and to their 'change of abode' ( $\mu \varepsilon \tau 0$ ixi $\alpha$ ), terms that come close to the connotations of the modern term 'migration'. ${ }^{32}$

\section{A Postcolonial Approach: In-Betweenness, Ambivalence and Polyphony}

Postcolonial literary theory has developed several concepts that have been successfully applied in recent studies on migrant literature in English, French

27 See Isayev 2015, 123, who prefers the terminology of mobility to that of migration.

28 On Greek and Roman types of Hellenism, see Whitmarsh 2009.

29 See e.g. Greenblatt 2010, 5-16. Tacoma 2016 and de Ligt and Tacoma 2016 are happy to use the notion of 'migration' for the Early Roman Empire.

30 On globalization and the Roman Empire, see Pitts and Versluys 2015; see also Nederveen Pieterse 2015; id. 2020, 50-57.

31 On 'migrancy', see Said 1993, 239-261; Smith 2004, 257; on ancient migrancy, see Connolly 2019.

32 On the (classical) Greek system of $\mu \varepsilon \tau 0$ xi $\alpha$, see Whitehead 1977. For the ancient Greek terminology of mobility, migration and wandering, see Garland 2014, 239-243. 
and German. ${ }^{33}$ Three of them will be particularly useful for examining migrant literature in the Early Roman Empire:

(a) In-betweenness: migrant literature does not exist in one place, but moves between spaces, cultures, and identities; it is this 'space in-between' that opens up the possibility of cultural hybridity. ${ }^{34}$ Applying this insight to the ancient world will have far-reaching consequences for our understanding of authors like Dionysius, Strabo, and Nicolaus, who are traditionally considered to be 'Greek authors'; they are in fact migrant authors moving between Greek, Roman and local traditions (Halicarnassus, Amasia, Damascus).

(b) Ambivalence: Salman Rushdie has underlined the "double perspective" of migrants, which helps them to contest and to question existing "truths" and "certainties". 35 This phenomenon is closely related to the "ambivalence' that defines the relationship between colonized and colonizer. According to postcolonial studies the colonized is in most cases not simply engaged in direct resistance or opposition against the colonizing power, but rather experiences a mix of "attraction and repulsion". ${ }^{36}$ Such ambivalence likewise characterizes Greek responses to Rome: pure anti-Romanism is rare, but Greek literature of the Early Roman Empire abounds in ambiguous, playful and ironical statements that somehow appear to question the authority of Rome and its rulers. Silence (i.e. ignoring the rulers) is another response to Rome that can be powerful through its ambivalence.

(c) Polyphony: “... the hybridity of a migrant's art signifies a freeing of voices, a technique for dismantling authority, a liberating polyphony that shakes off the authoritarian yoke". ${ }^{37}$ In the twenty-first century it is primarily the migrant novel that stages multiple characters with different perspectives on the world. In Greek imperial literature, there are many different ways in which polyphony is achieved: the perspectives of different characters can be voiced through character speech, including that of animals (see below); furthermore, the description of diverse local traditions, like that of Corinth, Amasia and Damascus (in geographical and historical works) can function as a powerful counternarrative against the dominant story of Rome; finally, addressing different local communities with different

33 E.g. Vlasta 2016; Nyman 2017.

34 Bhabha 1994, 5, 38; Smith 2004, 245; Ashcroft, Griffiths, and Tiffin 2013, 136.

35 Rushdie 1991, 12; cf. Smith 2004, 248.

36 Ashcroft, Griffiths, and Tiffin 1998, 13; cf. Bhabha 1994.

37 Boehmer 2005, 232. 
styles and messages (as in the epistles by Paul of Tarsus) is another way to bring out the rich polyphony of the Roman Empire.

While ambivalence and polyphony are typical aspects of migrant writing, they can of course also be found in other types of literature, like Homeric epic, Attic oratory or Greek tragedy. What distinguishes the ambivalence and polyphony of migrant literature is that they are primarily concerned with the power relations between different groups and directed against political authority. Ambivalence here means that a text may show contradictory attitudes to the Roman emperor or the power of Rome: praise and criticism, or flattery and irony at the same time. Polyphony here means the presentation of many different points of view that supplement, nuance, or undermine the perspective of Rome, Latin authors, or the Roman emperor. One can think of the voices of different characters with their opinions in a poem or series of poems (like the Garland of Philip), but also of the diversity of spaces and local traditions presented in Strabo's Geography. The intricate combination of in-betweenness, ambivalence and polyphony may occur in different genres and periods, but it is especially prominent in the Greek works of authors from different places around the Mediterranean who moved at some point to Rome.

'The Empire Writes Back' is a well-known phrase in postcolonial studies. A pun on the film Star Wars. The Empire Strikes Back, it was coined by Salman Rushdie in 1982 and later adopted as the title of an influential book on postcolonialism. ${ }^{38}$ It refers to the ways in which postcolonial voices respond to the culture of the colonial centre. In a similar way Greek literature of the Early Roman Empire tells us how 'The Roman Empire Writes Back' - that is, how the voices of migrant writers from local communities around the Mediterranean respond to the culture of Rome and its rulers.

The historian and rhetorician Dionysius of Halicarnassus moved to Rome in 3 о BC, as he tells us in his Roman Antiquities:

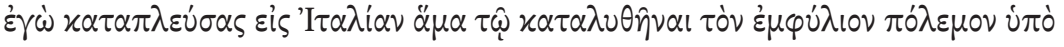

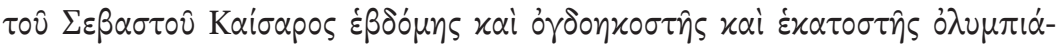

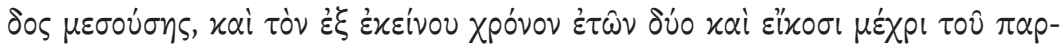

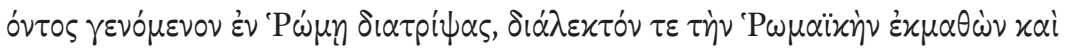

\footnotetext{
38 Ashcroft, Griffith and Tiffin 1989.
} 


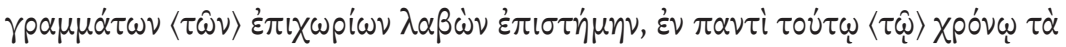

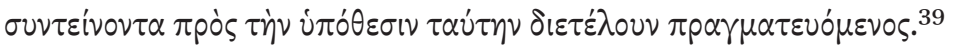

I sailed down to Italy at the very time that the civil war was put to an end by Augustus Caesar, in the middle of the one hundred and eightyseventh Olympiad; and having from that time to this present day, a period of twenty-two years, lived at Rome, having learned the language of the Romans, and having acquainted myself with their native writings, I have devoted myself during all that time to matters bearing upon my subject.

There is a close connection between spatial and temporal transitions here: Dionysius claims that the moment when he came to Rome in order to make a new beginning, the Romans were also just making a new beginning. Dionysius' personal migration narrative is thus intertwined with the transformation of the Roman Republic into the Empire. The in-betweenness of Dionysius' narrative is most obvious from his juxtaposition of two dates referring to the year 30 BC, one Roman and one Greek. Dionysius states that he came to Rome 'when the civil war was ended by Caesar Augustus, as the one hundred and eighty-seventh Olympiad was halfway'. Whereas the Roman date, expressed with the preposition $\alpha \mu \alpha$ and a substantivized infinitive construction ( $\alpha \mu \alpha \tau \hat{\omega}$

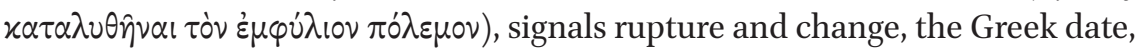

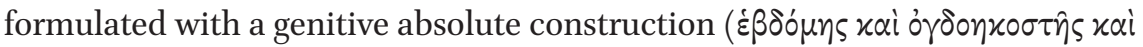

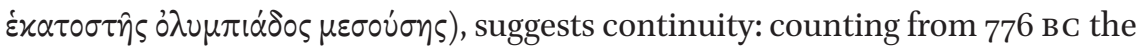
187 th Olympiad was only halfway in 3 о вC. Dionysius presents the two dates right next to each other, thereby inviting the reader to compare a Roman and a Greek perspective on time: the year that he migrated was the beginning of a new era for Rome, but the Greek calendar somehow downplays the importance of this moment of change by suggesting that it was just one year in the continuous line from 776 to $30 \mathrm{BC}$ and beyond.

Dionysius does not mention Halicarnassus. This is an interesting choice: is he silencing his place of origin because he intends to associate himself with classical Greece rather than with a multicultural town in Caria? In the preface to his On the Ancient Orators, Dionysius rejects the bad Asian influence on rhetoric, aligning himself with the Attic orators of classical Athens, like Lysias, Isocrates, Isaeus and Demosthenes. His negative remarks on rhetorical

39 D.H. 1.7.2. Translation adapted from Cary 1937. On Dionysius as a "migrant thinker", see Connolly 2019 (who does not discuss Dionysius' migration narrative). On Dionysius and Augustan Rome, see de Jonge 2008; Hunter and de Jonge 2019. 
teaching in Phrygia, Mysia and Caria might explain his silence on Halicarnassus in the Roman Antiquities. ${ }^{40}$

While Halicarnassus is not mentioned, Rome, the place of arrival, is very prominent in Dionysius' brief migration narrative. He portrays himself as a migrant who knows what to do in order to integrate with the society that received him: to learn the language and to study their culture, including their 'native writings' ( $\gamma p \alpha \mu \mu \alpha \dot{\tau} \tau \omega \nu\langle\tau \omega \nu\rangle) \dot{\varepsilon} \pi i \chi \omega \rho^{\prime}(\omega \nu)$. Not every migrant will end up writing a history of the culture to which they moved. Dionysius did. His Roman Antiquities is a specimen of migrant literature that is very much characterized by in-betweenness, ambivalence and polyphony. Writing about the early history of Rome from a Greek perspective, Dionysius argues that the earliest Romans were actually Greeks, that Rome was a Greek $\pi \dot{\lambda} \lambda ı$ and that Latin is a dialect of Greek. ${ }^{41}$ While Dionysius praises the earliest Romans, some passages of his work can be interpreted as questioning Roman rule; and by inserting a large number of (too?) long speeches, Dionysius gives voice to many different opinions on the character of Rome and Roman history. ${ }^{42}$

\section{Crinagoras on the Emperor and the Goat}

Another example can further illustrate the functions of in-betweenness, ambivalence and polyphony in Greek migrant literature. Crinagoras of Mytilene was a poet from the island of Lesbos, who travelled to Rome as an ambassador of his hometown.$^{43} \mathrm{He}$ became closely connected with the family of the Roman emperor, as several of his epigrams demonstrate. In the following poem he writes about a goat who accompanies emperor Augustus on a sea journey to (presumably) Greece:

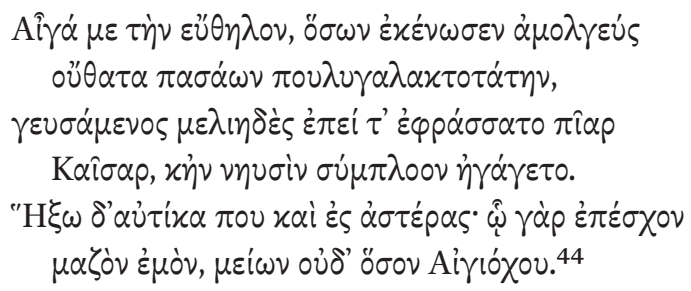

40 D.H. Orat. Vett. 1.5-7. See Hidber 1996 ad loc. and de Jonge 2014, 394-395.

41 See esp. D.H. 1.5.1-2; 1.90.1. For discussion, see Gabba 1991; Wiater 2011; and the essays in Hunter and de Jonge 2019.

42 On the speeches and the length of the Roman Antiquities, see Oakley 2019.

43 See the edition with introduction and commentary by Ypsilanti 2018. See also Gow and Page 1968. Bowie 2008 and Whitmarsh 2011 offer thought-provoking readings. 
I am the goat with the heavy udders, the richest in milk of all whose breast the dairy-pail has drained; when Caesar tasted and took note of my cream, sweet as honey, he made me his fellow-voyager even on shipboard. Soon I shall perhaps reach the stars; for he to whom I offered my breast is not the least inferior to the Aegis-bearer (i.e. Zeus).

Some readers have interpreted this poem as a mediocre product of superficial court flattery. ${ }^{45}$ Crinagoras abundantly praises emperor Augustus (here called Caesar), who will, as he expects, soon be deified. But how serious is this flattery when we observe that it is expressed by a goat, who is boasting that she, too, will reach the stars, as the emperor is so much enjoying her milk?46 The unmistakable irony adds a layer of ambivalence to the epigram; the voice of the goat joins the polyphonic chorus of Crinagoras' corpus of poems, which also stages a parrot that says 'Hail, Caesar' and many other speaking animals and human beings. ${ }^{47}$

The goat proudly presents herself as the 'fellow-voyager' ( $\sigma \dot{\nu} \mu \pi \lambda \circ 0 \varsigma$ ) of the Roman emperor. This makes her into a kind of migrant, who in this respect resembles the poet of the epigram: it is indeed plausible that the goat stands for Crinagoras, who feeds the emperor with poetry, just as the goat feeds him with honeysweet milk. Crinagoras seems indeed to have accompanied Augustus on a journey to Greece, an event that in a way mirrored, reversed and compensated for his own voyage from Lesbos to Rome. In-betweenness is crucial here: Crinagoras, the goat and Augustus all move between Rome and Greece, through an undefined space (the Mediterranean) that opens up the possibility for praise dressed up in playful irony. At the surface level Crinagoras' poem confirms the hierarchy between emperor and poet, between patron and client, between Rome and Greece; but at a deeper level, the exaggerated boasting of the goat (who hopes to join Augustus even when he will travel to the stars) undermines the hierarchy in a subtle way, which will have amused both the emperor and the (Greek and Roman) audience.

\section{Greek Literature of the Early Roman Empire as Migrant Literature}

The extant Greek literature dated between $27 \mathrm{BC}$ and AD 68 consists of the following genres and authors:

\footnotetext{
45 See the discussion of previous intrepretations in Ypsilanti 2018.

46 Bowie 2008, 234-235; Whitmarsh 2011; Ypsilanti 2018, 243.

$47 \quad$ AP $9.562=$ Crinagoras 24 .
} 
1. Epigram: A large number of poems collected in the Garland of Philip (later incorporated into the Palatine Anthology), including epigrams by Crinagoras of Mytilene, Antipater of Thessalonica, and Philip of Thessalonica; the epigrams of Lucillius were not included in the Garland of Philip.

2. Historiography and Biography:

a. Nicolaus' of Damascus, Collection of Foreign Customs, Life of Augustus and Autobiography (fragments);

b. Timagenes of Alexandria, On Kings and History of Augustus' Accomplishments (fragments and testimonies);

c. Dionysius of Halicarnassus, Roman Antiquities.

3. Jewish and Early Christian Literature:

a. Philo of Alexandria: nearly 50 treatises have survived; migration plays an important role in On the Embassy to Gaius, Against Flaccus, On the Migration of Abraham, and On the Life of Moses;

b. Paul of Tarsus: seven authentic epistles have been preserved.

4. Geography: Strabo of Amasia, Geography (17 books)

5. Rhetoric and Grammar: Dionysius of Halicarnassus (rhetorical works and critical essays), Apollodorus of Pergamon, Theodorus of Gadara, Caecilius of Caleacte, Didymus Chalcenterus (fragments).

All authors mentioned here could be called migrant writers, and, as far as we can tell, they all travelled to Rome at some point. To be sure, even authors who did not spend time in Rome but decided to stay in Greece, Asia Minor, Egypt or Syria (perhaps some of the poets of the Garland of Philip) will have experienced a certain 'in-betweenness', as they too lived in a world dominated by Roman political power, Greek culture, and regional (micro-)identities. But it appears that a remarkable number of authors did actually go to Rome, and that being in Rome had a great impact on their writing. Living at Rome seems to have fundamentally changed their perspective on the world. We can clearly see this in Dionysius' Roman Antiquities, in the writings on emperor Augustus by Nicolaus and Timagenes, in the epigrams that Crinagoras writes about Augustus, Tiberius and Marcellus, and in Strabo's Geography, which presents Rome as the centre of the Mediterranean world. Philo's diplomatic trip to Rome likewise had a fundamental impact on his life and writing, as has been argued recently. ${ }^{48}$ While many people outside of Rome and Italy will have experienced a degree of 'in-betweenness', it seems that being in Rome heightened that experience, as it made the differences between Greek, Roman and local perspectives more tangible, concrete, and urgent.

Niehoff 2018, 3; see below, section 8.3. 
In the remaining part of this article I will briefly discuss the genres mentioned above and their most important representatives. ${ }^{49}$ My aim in doing so is to show that the concept of migrant literature may cast new light on these different texts and thereby help us to achieve a better understanding of the diverse body of Greek literature of the Early Roman Empire.

\subsection{Epigram}

The one type of Greek poetry that survives from the Early Roman Empire is epigram. Our main source for early imperial Greek epigram is the Garland of Philip, an anthology that included short poems by at least 39 poets; 576 epigrams ( 3272 lines) can be securely attributed to this anthology. ${ }^{50}$ The Garland was compiled by Philip of Thessalonica, probably in the age of emperor Nero (54-68 AD). It contains epigrams that were written roughly between 6 о ВС and 50 AD. ${ }^{51}$ The Garland of Philip can be partly reconstructed because in the Byzantine period it was incorporated in the Palatine Anthology.

Rome plays a remarkable role in the Garland of Philip: many epigrams are concerned with or dedicated to the Roman emperor and his family, and many reflect on the relationship between Greek culture and the Roman world..$^{52}$ Some of the poets are only names for us, but in several cases we know more about their biography: they came from different places around the Mediterranean, travelled to Rome and were in many cases connected with and financially supported by Roman elite families. These migrant poets include Crinagoras of Mytilene, who travelled to Rome at least thrice as an ambassador of his hometown on the island on Lesbos (see above). He became closely connected to the imperial household: his poems include epigrams on Augustus, Germanicus, Marcellus, and Tiberius. ${ }^{53}$ Another prominent migrant poet is Antipater of Thessalonica, who lived in Rome between $20 \mathrm{BC}$ and AD 20 as a client of Lucius Calpurnius Piso Caesoninus. We know less about such poets as Marcus Argentarius, who seems to have adopted a Roman name, Diodorus of Sardis, who subversively compared the emperor's voyage to Rome to the Greek Neoptolemus' hostile attack on Troy (Diodorus 1 Gow-Page), and Thallus, who composed an intriguing epigram on the emperor's birthday (Thallus 2 Gow-Page).${ }^{54}$ Some epigrammatists have been preserved outside the Garland

49 Bowersock 1965, 122-139 offers a good overview of Greek literature under Augustus.

50 Edition: Gow and Page 1968. On the technical details of the Garland of Philip and other collections included in the Palatine Anthology, see Cameron 1993.

$5^{1} \quad$ Argentieri 2007; Höschele 2019.

$5^{2}$ See Bowie 2008; Whitmarsh 2011 (especially on patronage).

53 On Crinagoras, see Ypsilanti 2018. Bowie 2011 examines the role of Mytilene in the works of Crinagoras and other Greek imperial writers from Lesbos. 
of Philip: the Greek Anthology preserves more than one hundred epigrams by Lucillius, who was active under Nero. ${ }^{55}$

How does Greek epigram of the Early Roman Empire respond to Rome? Commentators of the past have denounced the quality of the poems of Crinagoras and his colleagues, characterizing the epigrams for Roman emperors as mere flattery. Recent scholarship however has shown that many of these poems contain an element of irony or critique. ${ }^{56}$ On closer inspection, the epigrams indeed turn out to be characterized by ambivalence, polyphony, and in-betweenness. The hierarchy between Roman emperor and Greek poet is undercut and disrupted in moments of irony; the Garland of Philip makes us listen to a multitude of voices, with different points of view, which include not just those of poets from different locations, but also those of goats, parrots, elephants, buildings, statues and other objects. These epigrams, several of which refer to voyages and travelling, move freely between the spaces of Rome, Greece and the Mediterranean, giving voice to perspectives that nuance and negotiate the dominant Roman narrative.

\subsection{Biography and Historiography}

Biography and historiography are two genres that bring us particularly close to the Roman emperor. ${ }^{57}$ Apart from the extensive Roman Antiquities composed by Dionysius of Halicarnassus, we have substantive fragments of the works of Nicolaus of Damascus and Timagenes of Alexandria.

(a) Nicolaus of Damascus (ca. 64 BC-AD 20) is one of the most intriguing migrant writers of the Augustan Age. Born in Damascus, he received a thorough Greek education, which prepared him for a career as an influential intellectual with powerful friends. In Jerusalem he became a close friend of king Herod, whom he accompanied several times to Rome. As an ambassador of the king of Judea, Nicolaus regularly visited Augustus, and thus, it seems, became the emperor's friend. Nicolaus was also the tutor of the children of Antonius and Cleopatra, either in Alexandria (3OS BC) or later in Rome (2OS BC), where he appears to have stayed for the final part of his life. ${ }^{58}$ Nicolaus' works included a universal history of the world, a collection of foreign customs, an autobiography and a biography of Augustus. Only fragments of these works have been preserved..$^{59}$

$55 \quad$ Floridi 2014 provides an edition with commentary.

56 Bowie 2008; Whitmarsh 2011.

57 See Hose 2018 on Augustus' appearance in Greek literature of the Early Roman Empire.

58 On Nicolaus' life, see Toher 2017, 1-21.

59 Editions: Malitz 2003; Parmentier and Barone 2011; Toher 2017. 
The traditional interpretation reads the Life of Augustus as a piece of imperial propaganda, supposing that it was a close translation into Greek of the emperor's own autobiography. Recent scholarship however has pointed out that Nicolaus presents the Roman emperor from a very Greek perspective, emphasizing Augustus' Greek education. ${ }^{60}$ Instead of understanding the works of Nicolaus of Damascus as either Roman or Greek, we could assess them as specimens of migrant literature, which move between Damascus, Jerusalem, Alexandria and Rome.

(b) Timagenes of Alexandria was brought from Egypt to Rome as a prisoner in 55 BC. As historian and rhetorician in Rome, Timagenes became a client of Gaius Asinius Pollio and (temporarily) a friend of emperor Augustus. One of his works was called On Kings. We possess a number of fascinating testimonies and fragments. ${ }^{61}$ Timagenes was known for his outspokenness and critical jokes, which resulted in a conflict with the emperor himself. ${ }^{62}$ Ancient sources tell us that Augustus expelled Timagenes from the imperial household, after which the latter burned the books in which he treated Augustus' achievements. ${ }^{63}$

Modern scholarship tends to see Timagenes as the voice of anti-Roman resistance, representing either Alexandrian or Greek opposition against Rome. ${ }^{64}$ Understanding him as a migrant writer will help us to overcome the limiting discourse that portrays Timagenes in terms of an opposition between Greek and Roman identities. According to one ancient source Timagenes was in fact a 'Syrian'.65 Much like his contemporary Dionysius of Halicarnassus, Timagenes was an intellectual who moved between cultures and between genres. Ambivalence seems characteristic of his responses to Rome. One of his more famous jokes is reported by Seneca:

Timagenes, felicitati urbis inimicus, aiebat Romae sibi incendia ob hoc unum dolori esse, quod sciret meliora surrectura quam arsissent. ${ }^{66}$

Timagenes, the enemy of the good fortune of the city, used to say that the only thing that upset him when there were fires in Rome was the knowledge that the buildings that had burned down would be replaced by even better ones.

6o Pausch 2011; see also Toher 2017.

$61 \quad$ McInerney and Roller $2012=$ Brill's New Jacoby 88 .

62 Woolf 2015; Hose 2018; Whitmarsh 2018.

63 Sen. Dial. 5 (=De ira 3).23.4-8.

64 For a discussion of earlier approaches, see Capponi 2018.

65 Ps.-Plu. Fluv. 6.3.

66 Sen. Ep. 91.13. Translation McInerney and Roller 2016. 
This statement has mostly been interpreted as evidence of Timagenes' antiRoman opposition, ${ }^{67}$ but one could argue that it in fact voices a complex and ambivalent response to Rome, which playfully combines undeniable admiration with biting sarcasm.

\subsection{Jewish and Christian Texts}

Jewish and Christian texts are often ignored in surveys of Greek literature, as modern academia is divided between fields like Classics, Judaism and Early Christianity. If, however, we understand Greek literature of the Early Roman Empire to be (migrant) literature written in the Greek language, we can go and should go beyond traditional disciplinary borders. Two prominent Jewish authors belong to the timeframe chosen here: Philo of Alexandria (ca. 2O BC-AD 5O) and Paul of Tarsus (ca. AD 5-67).

(a) Philo of Alexandria has been called a "Mediterranean thinker".68 Alexandria was a multicultural centre, inhabited by different groups: nonHellenized, native Egyptians, Hellenized Alexandrians, Hellenized Jews, and Romans. ${ }^{69}$ Philo was born in a Jewish elite family, and he received a thorough Greek education. At an important moment in his life he travelled to Rome in order to meet the Roman emperor Caligula. He stayed there for (presumably) three years (AD 38-41).

A recent biography argues that Philo's journey to Rome had a fundamental impact on his intellectual life. ${ }^{70}$ In AD 38 the Jewish population of Alexandria suffered from severe anti-Jewish violence during the riots (sometimes referred to as a 'pogrom') that broke out when statues of emperor Caligula had been placed in the Jewish synagogues. Philo presided over the Jewish embassy from Alexandria to emperor Gaius Caligula. He wrote an extensive report of this political enterprise, which is known as the treatise On the Embassy to Gaius. ${ }^{71}$ The work is in fact much more than a report of an embassy: it is also a fierce invective against emperor Caligula (who reigned AD 37-41), whose depravity Philo contrasts to the peaceful generosity of emperor Augustus. Until very recently, this fascinating treatise has been interpreted merely as a historical source for the events of AD 38 . Thanks to the work of scholars like Niehoff and Hartog, attention has been drawn to literary aspects of the work and to the importance of space, travel and locality in On the Embassy to Gaius. ${ }^{72}$

\footnotetext{
$67 \quad$ Since Fuchs 1964, 4.

68 Niehoff 2015.

69 Sly 1996; Schwartz 2009, 14-31.

$70 \quad$ Niehoff 2018, 3.

71 Smallwood 1970 provides a commentary.

72 Niehoff 2018; Hartog 2018; Hartog 2019.
} 
The concept of migrant literature would help us to explain Philo's ambivalence towards Rome (praising Augustus and Tiberius, blaming Caligula), his polyphony (his work citing in direct speech the Roman emperor, Petronius, governor of Syria, different members of the Jewish and the Greek embassies from Alexandria, and of course Philo himself), and his intermediary position between Egypt, Greece, and Rome (playing "a key role in the negotiations between East and West"). ${ }^{73}$ Was Philo Jewish, Greek, Alexandrian (Egyptian), and/or Roman? While Niehoff has argued that Philo may best be understood as a Mediterranean intellectual, we may also understand Philo as a writer of migrant literature. Niehoff has proposed to interpret Philo's works as anticipating the Second Sophistic (AD 50-250), drawing attention to parallels with Plutarch, Lucian and Philostratus. ${ }^{74}$ This is a useful perspective, but it will be even more fruitful to consider Philo in the context of early imperial Greek literature and to compare him with the non-Jewish writers of his own time: Philo must first of all be understood as a member of the group of (migrant) writers of the Early Roman Empire, as a colleague of Crinagoras, Strabo, Dionysius, Nicolaus, and (his fellow-townsman) Timagenes.

(b) Paul of Tarsus was born from Jewish parents in the South East of Asia Minor. He was educated in Jerusalem. After joining the Christian movement in ca. AD 32 he lived for a long time in Antioch. Later he travelled through Syria, Asia Minor, Macedonia and Greece. He worked in Corinth and Ephesus and as a prisoner spent time in Jerusalem, Caesarea and, finally, Rome. Paul writes in Greek and is to a large extent familiar with Greek rhetorical styles and philosophical notions. ${ }^{75}$ Among the epistles that bear the name of Paul, seven are accepted as authentic: Romans, 1 Corinthians, 2 Corinthians, Galatians, Philippians, 1 Thessalonians and Philemon. ${ }^{76}$

The Epistle to the Romans (probably written AD 57 in Corinth) is especially relevant for our understanding of Paul's response to Greek and Roman culture. This letter aimed to prepare the Christian community of Rome (which consisted of both Jews and pagans) for Paul's visit to the city. Paul's attitude towards the Roman rulers could be described as ambivalent. He acknowledges that 'everyone must submit to governing authorities' like that of the Roman emperor (Romans 13:1); but 'all authority comes from God, and those in positions of authority have been placed there by God' (13:2). Some scholars have

73 Niehoff 2018, 1-2.

74 Niehoff 2018, 18-22.

75 E.g. Breytenbach 2015; Thom 2015.

76 Horn 2013. 
argued that Paul's teaching was directly opposed to the Roman Empire; ${ }^{77}$ other scholars have insisted that 'the Roman Empire was insignificant to Paul'.78

What is missing from this important debate so far is the perspective of migrant literature. A key element in Paul's Epistle to the Romans is the idea that God does not have one special people and is not there for the Jews only. Israel keeps certain privileges, but peoples of all parts of the world can join the religious movement of Jesus: 'Is God the God of Jews only? Is he not the God of other peoples too? Yes, of other peoples too, since there is only one God' (Romans 3:29-30). It is plausible that his own experiences as a migrant writer, moving between different cultures, contributed to this inclusive approach. ${ }^{79}$ His epistles adopt different tones, as they address different audiences: this polyphony is indeed typical of the migrant writer between Romans, Corinthians, Galatians, Philippians and Thessalonians.

\subsection{Geography}

One of the most productive writers of the Early Roman Empire was of course Strabo of Amasia (ca. 64 BC-AD 24). His History is lost, but we still possess his Geography, a survey of the world in seventeen books. ${ }^{80}$ The work was composed under emperor Tiberius. Strabo was a migrant writer with a complex identity. His name suggests that he was a Roman citizen, but Strabo came from Pontus, a Hellenistic kingdom near the Black Sea, which was annexed by Rome. Later authors characterized him as Cappadocian. He travelled widely between Pontus, Armenia, Egypt, Ethiopia and Italy, partly in the company of his patron Aelius Gallus, the Roman prefect of Egypt. Strabo probably knew Latin and Cappadocian, but he wrote in Greek, and throughout his work he presents Greek culture as superior to that of Rome.

Strabo's attitude towards Rome can be characterized as ambivalent. ${ }^{81}$ On the one hand, he praises emperor Augustus for his efficient government and great building projects; and, more ambiguously, for his training with Greek intellectuals (thus presenting Roman rule as dependent on Greek learning). On the other hand, he explicitly labels the Romans as 'more refined barbarians' (1.4.9) and criticizes their ignorance of art. While it has been argued that the geographer Pausanias (second century AD) by zooming in on local histories and identities engages in an act of "discursive resistance" against Rome, ${ }^{82}$

77 Esp. Wright 2002.

78 Barclay 2011, 363-387.

79 Whitmarsh 2010, 12 portrays Paul as a "mediating figure"; cf. Baslez 2015.

8o On Strabo, see Dueck 200o; Clarke 2001; Dueck, Lindsay and Pothecary 2009; Dueck 2017.

81 On Strabo and Rome, see Madsen 2017 and Purcell 2017.

82 Whitmarsh $2013 \mathrm{a}$. 
Strabo's work, composed in a period that was pivotal for the founding of the Roman Empire, still awaits a systematic analysis in similar terms. One moment of 'discursive resistance' in Strabo's work that has been identified is the passage on the destruction of Corinth by the Romans (8.6.23), where Strabo implicitly criticizes the Roman disregard for ancient Greek statues and paintings. ${ }^{83}$

Recent interpretations have rightly drawn attention to the tension between Greece and Rome in Strabo's work. ${ }^{84}$ But it is crucial to go beyond the traditional opposition of 'being Greek under Rome' and to recognize the importance of 'microidentities' in the Geography, like those of Amasia (Strabo's hometown) and Corinth, but also Croton, Colophon, Crocodilopolis, and the numerous other places that figure in Strabo's account of the Roman Empire. ${ }^{85}$ Strabo's description of the Roman world perfectly demonstrates how globalization and localization go hand in hand. While Strabo's project as a whole can be seen as an Augustan enterprise that somehow confirms the success of the Roman empire, stretching from Spain to Syria and from Egypt to Gaul, ${ }^{86}$ his focus on numerous specific regions around the Mediterranean draws attention to the enormous diversity that characterized the Roman Empire. One way to look at Strabo's Geography is thus that it portrays 'The Empire Writing Back'.87 The concept of migrant literature opens up new perspectives on Strabo's ambivalence towards Rome, his polyphony (giving voice to the traditions of many communities around the Mediterranean), and his in-betweenness, as a migrant writer between Pontus, Cappadocia, Greece, Rome and so many other cultural identities that his work evokes.

\section{9}

\section{Conclusion}

This brief survey of Greek literature of the Early Roman Empire could be further extended with migrant writers whose works survive in fragments only. They include rhetoricians like Apollodorus of Pergamon, Theodorus of Gadara, and Caecilius of Caleacte, who all migrated to Rome, and the grammarian Didymus

\footnotetext{
$83 \quad$ See Dueck 2000, 121.

84 Dueck 200o; Madsen 2017; Purcell 2017.

85 On the urgency of moving beyond the paradigm of 'Greece versus Rome', see e.g. Jones 2010, 111. On microidentities, see Whitmarsh 2010.

86 Clarke 2001, 210-213.

87 Cf. Ashcroft, Griffith and Tiffin 1989 on postcolonial literature (and see above on Rushdie 1982).
} 
Chalcenterus, who seems to have lived in Alexandria and Rome. ${ }^{88}$ The authors of this period whose lives we can reconstruct were travellers or migrants, and this had a substantial impact on their literary output. Adopting the concept of migrant literature casts new light on the literature written in Greek of the Early Roman Empire. The extant texts of this period all turn out to be closely related to the cultural mobility that characterized the globalized Roman world, so much that migration seems to have been a condition for writing literature in this age. The authors of this period were not 'Greek under Rome', then, but rather engaged in complex triangular relationships between Greece, Rome and their local communities. Their writings are in most cases not to be categorized as evidently pro- or anti-Roman, but rather characterized by ambivalence, polyphony and in-betweenness, for which each literary genre developed its own specific tools. The concept of migrant literature also helps us to see intriguing connections between texts that are usually kept apart: Crinagoras and Philo are not usually paired, nor are Paul and Strabo. If we go beyond traditional categories and look at these different texts from a migrant perspective, we will recognize fascinating dialogues between spaces, genres, and traditions.

\section{Acknowledgments}

This article is based on ideas that I have also presented in a research proposal submitted to the Netherlands Organization of Scientific Research (NWO) in September 2020. I wish to thank Joy Connolly, Richard Hunter, Ineke Sluiter, Rens Tacoma and Greg Woolf for their helpful comments and valuable suggestions. I am also very grateful to Gerard Boter, who is honoured with this special issue of Mnemosyne. His learned, deeply honest and cheerfully enthusiastic approach to ancient literature has been and will be a great inspiration.

\section{Bibliography}

Argentieri, L. (2007). Meleager and Philip as Epigram Collectors. In: P. Bing and J.S. Bruss, eds., Brill's Companion to Hellenistic Epigram. Down to Philip, Leiden, pp. 147-164.

Ashcroft, B., Griffiths, G., and Tiffin, H. (1989). The Empire Writes Back. Theory and Practice in Post-Colonial Literatures. London.

88 Caecilius, Apollodorus and Theodorus have been edited by Woerther 2013; Woerther 2015. For Claudius Didymus, see Schmidt 2010. 
Ashcroft, B., Griffiths, G., and Tiffin, H. (2013). Postcolonial Studies. The Key Concepts. London/New York.

Barclay, J.M.G. (2011). Pauline Churches and Diaspora Jews. Tübingen.

Baslez, M.-F. (2015). Paul et l'émergence d'un monde 'gréco-romain'. Réflexions sur la romanité de l'apôtre. In: C. Breytenbach, ed., pp. 29-45.

Bhabha, H. (1994). The Location of Culture. London.

Boehmer, E. (2005). Colonial and Postcolonial Literature. Migrant Metaphors. Oxford.

Bowersock, G. (1965). Augustus and the Greek World. Oxford.

Bowie, E.L. (1970). Greeks and their Past in the Second Sophistic. P\&P 46, pp. 3-41.

Bowie, E.L. (2008). Luxury Cruisers. Philip's Epigrammatists between Greece and Rome. Aevum(ant) 8, pp. 223-259.

Bowie, E.L. (2011). Men from Mytilene. In: T.A. Schmitz and N. Wiater, eds., pp. 181-195.

Breytenbach, C., ed. (2015). Paul's Graeco-Roman Context. Leuven.

Cameron, A. (1993). The Greek Anthology from Meleager to Planudes. Oxford.

Capponi, L. (2018). A Disillusioned Intellectual. Timagenes of Alexandria. In:P. Bosman, ed., Intellectual and Empire in Greco-Roman Antiquity, Abingdon, pp. 43-62.

Cary, E. (1937). The Roman Antiquities of Dionysius of Halicarnassus. London/ Cambridge, MA.

Clarke, K. (2001). Between Geography and History. Hellenistic Constructions of the Roman World. Oxford.

Connolly, J. (2007). Being Greek/Being Roman. Hellenism and Assimilation in the Roman Empire. In: W. Brandes et al., Millennium 4/2007. Jahrbuch zu Kultur und Geschichte des ersten Jahrtausends n. Chr., Berlin/New York, pp. 21-42.

Connolly, J. (2019). Envoi. Migrancy. In: R. Hunter and C.C. de Jonge, eds., pp. 267-277.

Dueck, D. (200o). Strabo of Amasia. A Greek Man of Letters in Augustan Rome. London/ New York.

Dueck, D., ed. (2017). The Routledge Companion to Strabo. London.

Dueck, D., Lindsay, H., and Pothecary, S., eds. (2009). Strabo's Cultural Geography. The Making of a Kolossourgia. Cambridge.

Dupont, F., and Valette-Cagnac, E., eds. (2005). Façons de parler grec à Rome. Paris.

Floridi, L. (2014). Lucillio, Epigrammi. Introduzione, testo critico, traduzione e commento. Berlin/Boston.

Fuchs, H. (1964). Der geistige Widerstand gegen Rom in der antiken Welt. Berlin.

Gabba, E. (1991). Dionysius and the History of Archaic Rome. Berkeley/Los Angeles/ Oxford.

Garland, R. (2014). Wandering Greeks. The Ancient Greek Diaspora from the Age of Homer to the Death of Alexander the Great. Princeton/Oxford.

Garland, R. (2018). Involuntary Displacement in Livy Books 1-5. In: J. Driessen, ed., An Archaeology of Forced Migration. Crisis-Induced Mobility and the Collapse of the 13th c. BCE Eastern Mediterranean, Louvain-La-Neuve, pp. 101-106. 
Goldhill, S., ed. (2001). Being Greek under Rome. Cultural Identity, the Second Sophistic and the Development of Empire. Cambridge.

Gow, A.S.F., and Page, D.L., eds. (1968). The Greek Anthology, The Garland of Philip and Some Contemporary Epigrams. Cambridge.

Greenblatt, S. et al. (2010). Cultural Mobility. A Manifesto. Cambridge.

Hartog, P.B. (2018). Space and Travel in Philo's Legatio ad Gaium. The Studia Philonica Annual 30, pp. 71-92.

Hartog, P.B. (2019). Contesting Oikoumenē. Resistance and Locality in Philo's Legatio ad Gaium. In: G.H. van Kooten and J.T.A.G.M. van Ruiten, eds., Intolerance, Polemics, Debate in Antiquity. Politico-Cultural, Philosophical, and Religious Forms of Critical Conversation in the Ancient Near Eastern, Biblical, Graeco-Roman, and Early Islamic Worlds, Leiden, pp. 205-231.

Hezser, C. (2011). Jewish Travel in Antiquity. Tübingen.

Hidber, T. (1996). Das klassizistische Manifest des Dionys von Halikarnass. Stuttgart/ Leipzig.

Horn, F.W., ed. (2013). Paulus Handbuch. Tübingen.

Höschele, R. (2019). Greek Epigram in Rome in the First Century CE. In: C. Henriksén, ed., A Companion to Ancient Epigram, Hoboken, pp. 475-49o.

Hose, M. (2018). Augustus' Eintritt in die griechische Literatur. Hermes 146, pp. 23-40.

Hunter, R., and de Jonge, C.C., eds. (2019). Dionysius of Halicarnassus and Augustan Rome. Rhetoric, Criticism and Historiography. Cambridge.

Hutchinson, G.O. (2020). Motion in Classical Literature. Homer, Parmenides, Sophocles, Ovid, Seneca, Tacitus, Art. Oxford.

Isayev, E. (2015). Polybius' Global Moment and Human Mobility through Ancient Italy. In: M. Pitts and M.J. Versluys, eds., pp. 123-140.

Isayev, E. (2017). Migration, Mobility and Place in Ancient Italy. Cambridge.

Jones, C. (2010). Ancestry and Identity in the Roman Empire. In: T. Whitmarsh, ed., pp. 111-124.

de Jong, I.J.F., ed. (2012). Space in Ancient Greek Literature. Studies in Ancient Greek Narrative. Leiden/Boston.

de Jonge, C.C. (2008). Between Grammar and Rhetoric. Dionysius of Halicarnassus on Language. Linguistics and Literature. Leiden/Boston.

de Jonge, C.C. (2014). The Attic Muse and the Asian Harlot. Classicizing Allegories in Dionysius and Longinus. In: J. Ker and C. Pieper, eds., Valuing the Past in the Greco-Roman World, Leiden/Boston, pp. 388-409.

König, J., and Wiater, N., eds. (forthcoming). Late Hellenistic Greek Literature in Dialogue. Cambridge.

Kuhrt, A., and Sherwin-White, S., eds. (1987). Hellenism in the East. Berkeley/Los Angeles. 
de Ligt, L., and Tacoma, L.E., eds. (2016). Migration and Mobility in the Early Roman Empire. Leiden/Boston.

Madsen, J.M. (2017). Looking in from the Outside. Strabo's Attitude Towards the Roman People. In D. Dueck, ed., pp. 35-44.

Malitz, J. (2003). Nicolaus Damascenus, Leben des Kaisers Augustus. Darmstadt.

Mardorossian, C.M. (2002). From Literature of Exile to Migrant Literature. Modern Language Studies 35, pp. 15-33.

McInerney, J., and Roller, D.W. (2016). Timagenes of Alexandria (88). In: I. Worthington (ed.), Brill's New Jacoby. Consulted online on 18 September 2020.

Millar, F. (1987). Empire, Community and Culture in the Roman Near East. Greeks, Syrians, Jews and Arabs. Journal of Jewish Studies 38, pp. 149-150.

Millar, F. (1993). The Roman Near East, 31 BC-AD 337. Cambridge.

Nederveen Pieterse, J. (2015). Ancient Rome and Globalisation. Decentring Rome. In: M. Pitts and M.J. Versluys, eds., pp. 225-239.

Nederveen Pieterse, J. (2020). Globalization and Culture. Global Mélange. 4th ed. New York/London.

Niehoff, M.R. (2015). Wie wird man ein mediterraner Denker? Der Fall Philon von Alexandria. In: R. Faber and A. Lichtenberger, eds., Ein pluriverses Universum. Zivilisationen und Religionen im antiken Mittelmeerraum, Paderborn, pp. 355-367.

Niehoff, M. (2018). Philo of Alexandria. An Intellectual Biography. New Haven.

Nyman, J. (2017). Displacement, Memory, and Travel in Contemporary Migrant Writing. Leiden 2017.

Oakley, S.P. (2019). The Expansive Scale of the Roman Antiquities. In: R. Hunter and C.C. de Jonge, eds., pp. 127-16o.

Parmentier, E., and Barone, F.P., eds. (2011). Nicolas de Damas, Recueil de coutumes; Vie d'Auguste; Autobiographie. Paris.

Pausch, D. (2011). Augustus chlamydatus. Greek Identity and the bios Kaisaros by Nicolaus of Damascus. In: T.A. Schmitz and N. Wiater, eds., pp. 143-162.

Pitts, M., and Versluys, M.J., eds. (2015). Globalisation and the Roman World. World History, Connectivity and Material Culture. Cambridge.

Purcell, N. (2017). 'Such is Rome ....' Strabo on the 'Imperial Metropolis'. In: D. Dueck, ed., pp. 22-34.

Richter, D.S., and Johnson, W.A., eds. (2017). The Oxford Handbook of the Second Sophistic. Oxford.

Rushdie, S. (1982). The Empire Writes Back with a Vengeance. London Times 3July 1982. Rushdie, S. (1991). Imaginary Homelands. Essays and Criticism 1981-1991. London.

Said, E. (1993). Culture and Imperialism. London.

Savin, A., ed. (2013). Exile and Migration. Charting New Literary and Artistic Territories. Cambridge. 
Schmidt, M. (2010). Didymi Chalcenteri grammatici Alexandrini fragmenta quae supersunt omnia. Cambridge [first edition 1854].

Schmitz, T.A., and Wiater, N., eds. (2011). The Struggle for Identity. Greeks and Their Past in the First Century BCE. Stuttgart.

Schwartz, D.R. (2009). Philo, his Family, and his Times. In: A. Kamesar, ed., The Cambridge Companion to Philo, Cambridge, pp. 9-31.

Sly, D.I. (1996). Philo's Alexandria. London/New York.

Smallwood, E.M., ed. (1970). Philonis Alexandrini Legatio ad Gaium. Edited with Introduction, Translation and Commentary. Leiden.

Smith, A. (2004). Migrancy, Hybridity, and Postcolonial Literary Studies. In: N. Lazarus, ed., The Cambridge Companion to Postcolonial Literary Studies, Cambridge, pp. 241-261.

Swain, S. (1996). Hellenism and Empire. Language, Classicism, and Power in the Greek World AD 50-250. Oxford.

Tacoma, L.E. (2016). Moving Romans. Migration to Rome in the Principate. Oxford.

Thom, J.C. (2015). Paul and Popular Philosophy. In: C. Breytenbach, ed., Paul's Graeco-Roman Context, Leuven, pp. 47-74.

Toher, M., ed. (2017). Nicolaus of Damascus, The Life of Augustus and the Autobiography. Edited with Introduction, Translation and Commentary. Cambridge.

Versluys, M.J. (2016). The Global Mediterranean. A Material-Cultural Perspective. In: A. Geurds, P. Lane et al., eds., The Routledge Handbook of Globalisation and Archaeology, London, pp. 597-6o1.

Vlasta, S. (2016). Contemporary Migration Literature in German and English. A Comparative Study. Leiden.

Wallace-Hadrill, A. (2008). Rome's Cultural Revolution. Cambridge/New York.

White, P. (1995). Geography, Literature and Migration. In: R. King et al., eds., Writing Across Worlds. Literature and Migration, London/New York, pp. 1-19.

Whitehead, D. (1977). The Ideology of the Ancient Metic. Cambridge.

Whitmarsh, T. (2001a). Greek Literature and the Roman Empire. The Politics of Imitation. Oxford.

Whitmarsh, T. (2001b). 'Greece is the World'. Exile and Identity in the Second Sophistic. In: S. Goldhill, ed., Being Greek under Rome. Cultural Identity, the Second Sophistic and the Development of Empire, Cambridge, pp. 269-305.

Whitmarsh, T. (2005). The Second Sophistic. Oxford.

Whitmarsh, T. (2009). Greece and Rome. In: G. Boys-Stones, B. Graziosi, and P. Vasunia, eds., The Oxford Handbook of Hellenic Studies, Oxford, pp. 114-128.

Whitmarsh, T., ed. (2010). Local Knowledge and Microidentities in the Imperial Greek World. New York/Cambridge.

Whitmarsh, T. (2011). Greek Poets and Roman Patrons in the Late Republic and Early Empire. In T.A. Schmitz and N. Wiater, eds., pp. 197-212. 
Whitmarsh, T. (2013a). Beyond the Second Sophistic. Adventures in Greek Postclassicism. Berkeley/Los Angeles/London.

Whitmarsh, T. (2013b). Resistance is Futile? Greek Literary Tactics in the Face of Rome. In: P. Schubert, ed., Les grecs héritiers des Romains = Entretiens Fondation Hardt 49, Geneva/Vandœuvres, pp. 57-85.

Whitmarsh, T. (2018). How to Write Anti-Roman History. In D.S. Allen, P. Christesen, and P. Millett, eds., How to Do Things with History, Oxford, pp. 365-39o.

Wiater, N. (2011). The Ideology of Classicism. Language, History, and Identity in Dionysius of Halicarnassus. Berlin/New York.

Woerther, F. (2013). Apollodore de Pergame, Théodore de Gadara, Fragments et témoignages. Paris.

Woerther, F. (2015). Caecilius de Calè-Actè, Fragments et témoignages. Paris.

Woolf, G. (1994). Becoming Roman Staying Greek. Cultural Identity and Civilizing Process in the Roman East. PCPhS 40, pp. 116-143.

Woolf, G. (2010). The Local and the Global in the Graeco-Roman East. In: T. Whitmarsh, ed., pp. 189-200.

Woolf, G. (2016). Movers and Stayers. In: L. de Ligt and L.E. Tacoma, eds., pp. 438-461.

Wright, N.T. (2002). The Letter to the Romans. Introduction, Commentary and Reflections. In: The New Interpreter's Bible. Vol. 10, Nashville, pp. 395-770.

Ypsilanti, M. (2018). The Epigrams of Crinagoras of Mytilene. Oxford. 